\title{
Producción científica e Índice h ¿cómo los alcanzamos?
}

Nuestros países latinoamericanos se caracterizan porque invierten muy poco en investigación (Chile gasta apenas el 0,36\% del PIB, muy lejos del 2,6\% promedio que invierten los países de la OCDE) y lamentablemente, la investigación es principalmente financiada con recursos estatales. Para quienes trabajamos por muchos años en la academia realizando actividades de docencia e investigación (entre otras) con los escasos recursos disponibles, muchas veces nos sentimos agobiados por la cienciometría (ciencia que estudia la producción científica), lo que permite evaluar la calidad de nuestra producción intelectual (o científica) a través de la calidad de las revistas en que publicamos en función de su factor de impacto y quartil, cuántos investigadores leen nuestras publicaciones y cuántas veces citan nuestros resultados, lo que se traduce en un Índice h (indicador importante de la productividad y el impacto del trabajo científico de un investigador). Éste índice, sin duda que es una buena herramienta para la medición de la productividad científica de un investigador. Sin embargo, como sólo identifica las veces que se cita un trabajo (asumiendo que es por sus buenos aportes), si un trabajo es citado varias veces producto de sus conclusiones equivocadas, ese investigador, incrementará su Índice h por causas de sus errores. Después de 35 años de investigación, he visto que muchos colegas de mi época finalmente terminan siendo superados por las exigencias de producción científica y a otros, los más jóvenes, les complica el ingreso a este mundo controlado por la cienciometría. La pregunta es ¿cómo superar las exigencias de producción científica que nuestras universidades (o centros de investigación) nos imponen en función de la cienciometría y sus indicadores?

Como Decano de la Facultad, a los investigadores jóvenes que recién se inician en esta importante, hermosa y a veces estresante actividad, el consejo que les doy ( $y$ que ahora quiero compartir con los lectores de esta importante revista a la espera de que sea de utilidad para más de alguno de ellos), es que deben realizar un trabajo en equipo y muldisciplinario. Para mí, el investigador que cree que la investigación que "él" desarrolla es la más importante y la puede hacer solo, será devorado por la cienciometría debido a sus bajos indicadores. Hoy, el éxito de un investigador está asociado al trabajo en equipo y los investigadores exitosos son aquellos que se vinculan con colegas de diferentes profesiones y/o posgrados de otras instituciones que complementan sus resultados con otras variables y/o técnicas que les permiten dar mayor sustento a sus resultados y conclusiones, y con ello, optar a que revistas de mayor Factor de Impacto y mejor quartil, publiquen sus trabajos. Por ej. Un espermatólogo que trabaja en piscicultura, querrá saber si los espermatozoides de sus peces tienen actividad flagelar y capacidad fecundante porque son las funciones espermáticas más importantes para un piscicultor y será atractivo para revistas del área acuícola. Pero si sus observaciones son complementadas con parámetros biofísicos como velocidad espermática utilizando sistemas CASA y citometría de flujo determinando parámetros de integridad de membrana plasmática, potencial de membrana mitocondrial, producción de estrés oxidativo (entre otros), sumará nuevas revistas (y de mayor factor de impacto y quartil) que quieran publicar sus trabajos. Si le agrega indicadores moleculares como fragmentación de ADN, producción y consumo de ATP, translocación de fosfolípidos, etc. se incrementará aún más sus opciones de publicar en mejores revistas. Es evidente, que el gametólogo no puede aplicar y determinar todas estas técnicas, pero sí puede interpretar sus resultados y dar mayor sustento a sus conclusiones.

Entonces, a los investigadores jóvenes que leen esta editorial, los invito a levantar su mirada y buscar los colegas más cercanos a su temática, si están en otras instituciones o en otros países, qué importa?... HOY MÁS QUE NUNCA SABEMOS QUE EL MUNDO ES UN PAÑUELO iiii para contarles de sus investigaciones y la forma en que pueden complementarlas. A la hora de publicar, habrá que discutir quién va de primer autor o autor de correspondencia ..... (en su primer artículo multidisciplinario) iiii y en la mejor revista ...

Prof. Dr. Iván Valdebenito Isler.

Decano Facultad Recursos Naturales.

Universidad Católica de Temuco. CHILE

Email: ivisler@uct.cl 


\section{Scientific production and the h-index: how do we deal with this?}

Our Latin-American countries are characterised by investing very little in research (e.g. Chile spends just 0.36\% of its GDP which is far from the average $2.6 \%$ invested by the Organisation for Economic Co-operation and Development (OECD) countries), research unfortunately being financed by state resources. Those of us having worked for many years as teachers and researchers in the academic field with the limited resources available have often felt overwhelmed by scientometry (the study and valuation of scientific production by quantitative means). This enables the quality of our intellectual and/or scientific production to be evaluated via the quality of the journals in which we publish our material regarding their impact factors (IF) and quartiles (Q), the amount of researchers who read our publications and how many times they cite our results. This results in the h-index (an important indicator of a researcher's productivity and impact regarding her/his scientific work).

Such index is undoubtedly a good tool for measuring a researcher's scientific productivity. However, as it only identifies the amount of times a particular piece of work has been cited (assuming that this has been for its good/strong contribution to that field), then if certain work has been cited several times regarding its erroneous conclusions then the author/researcher's h-index will increase due to such errors. After having been engaged in the field of research for 35 years now, I have seen many of my contemporaries finally becoming overwhelmed by the demands of scientific production and others, much younger, finding it difficult to enter this world controlled by scientometrics. The question concerns how to overcome the demands of scientific production imposed on us by our universities or research centres regarding scientometry and its indicators?

The advice I would give to young researchers recently embarking on this significant, beautiful and, at times, stressful activity, as Dean of the Natural Resources Faculty, is that they must learn to work as a team and in a multidisciplinary manner. I wish to share the same advice with the readers of this important journal, hoping that it will be useful for more than just one of them. I think that researchers who believe that the research they are involved in is more important than anything else could be and that they can do it alone will be devoured by scientometrics due to low h-index indicators.

Researchers' success today is associated with their attitude towards teamwork. Successful researchers are those who manage/make the effort to become involved with colleagues from different professions and/or postgraduates from other institutions, thereby complementing their results with other variables and/or techniques enabling them to provide greater support for their results and conclusions. This, in turn, enables them to selectively submit their work by opting to send it for consideration for publication to (indexed) journals having higher impact factors and better quartiles.

For example, spermatologists working in fish farming (pisiculture) will want to know whether their fishes' sperms have flagellar activity and fertilising capability because these are the most important sperm functions for a fish farmer and material related to this will be attractive for journals specialising in aquiculture. Nonetheless, if their observations are complemented by material regarding biophysical parameters, such as sperm speed, using computer-assisted sperm analysis (CASA) systems and flow cytometry for determining parameters regarding plasmatic membrane integrity, mitochondrial membrane potential and oxidative stress production, this will make their material more attractive for new journals (having greater impact factor and better quartile) who may wish to publish their work. If molecular indicators such as DNA fragmentation, ATP production and consumption, phospholipid translocation, etc., are added this will further increase their options for being becoming published in better journals. It is evident that the aforementioned spermatologists/gametologists cannot use and determine all these techniques; however, they can interpret their results thereby providing greater support for their conclusions.

I thus invite young researchers reading this editorial to look beyond their immediate surroundings and seek out those colleagues working most closely in their chosen field/ on pertinent topics; what does it matter if they happen to be working in other institutions or other countries?... Today, more than ever, we know that it is a small world iiii for telling interested colleagues about one's research and how they can complement it. When it comes to publishing, there will have to be discussion about who is to be cited as first author and/or corresponding author ..... (in one's first multidisciplinary article) iiii and in the best journal ...

Dr Iván Valdebenito Isler,

Dean of the Natural Resources Faculty,

Temuco Catholic University, Chile

Email: ivisler@uct.cl 


\title{
Produção científica e Î́ndice h, como os conseguimos?
}

\begin{abstract}
Nossos países latino-americanos são caracterizados pelo fato de investirem muito pouco em pesquisa (o Chile gasta apenas $0,36 \%$ do PIB, longe da média de 2,6\% que os países da OCDE investem) e, infelizmente, a pesquisa é financiada principalmente com recursos estatais. Para aqueles que trabalham por muitos anos na academia realizando atividades de ensino e pesquisa (entre outros) com os recursos limitados disponíveis, geralmente nos sentimos sobrecarregados com a cienciometria (ciência que estuda a produção científica), que nos permite avaliar a qualidade de nossa produção intelectual (ou científica) através da qualidade dos periódicos em que publicamos com base em seu fator de impacto e quartil, quantos pesquisadores leem nossas publicações e quantas vezes citam nossos resultados, o que se traduz em um Índice h (indicador importante da produtividade e o impacto do trabalho científico de um pesquisador). Esse índice, sem dúvida, é uma boa ferramenta para medir a produtividade científica de um pesquisador. No entanto, como apenas identifica as vezes em que um trabalho é citado (assumindo que sejam boas suas contribuições), se um trabalho for citado várias vezes como resultado de conclusões erradas, esse pesquisador aumentará seu índice h devido a seus erros. Após 35 anos de pesquisa, vi que muitos colegas do meu tempo finalmente acabam sendo superados pelas demandas da produção científica e outros, os mais jovens, acham difícil entrar neste mundo controlado pela cienciometria. A questão é como superar as demandas de produção científica que nossas universidades (ou centros de pesquisa) nos impõem com base na cienciometria e seus indicadores?
\end{abstract}

Como Decano da Faculdade, para os jovens pesquisadores que estão apenas começando nesta atividade importante, bonita e às vezes estressante, os conselhos que dou (e agora quero compartilhar com os leitores desta importante revista, esperando que seja útil para mais de um deles), é que eles devem realizar trabalho em equipe e trabalho multidisciplinar. Para mim, o pesquisador que acredita que a pesquisa que "ele" desenvolve é a mais importante e pode ser feita sozinha, será devorado pela cienciometria devido aos seus baixos indicadores. Hoje, o sucesso de um pesquisador está associado ao trabalho em equipe, e pesquisadores de sucesso são aqueles que se relacionam com colegas de diferentes profissões e / ou pós-graduações de outras instituições que complementam seus resultados com outras variáveis e / ou técnicas que Ihes permitem dar maior robustez a seus resultados e conclusões, para optar por revistas com maior fator de impacto e melhor quartil onde publicar seus trabalhos. Por exemplo. Um espermatologista que trabalha na piscicultura deseja saber se o esperma do um peixe tem atividade flagelar e capacidade de fertilização, porque são as funções espermáticas mais importantes para um criador de peixes e será atrativo para as revistas de aquicultura. Mas se suas observações forem complementadas com parâmetros biofísicos, como a velocidade do esperma usando sistemas CASA e citometria de fluxo, determinando parâmetros de integridade da membrana plasmática, potencial da membrana mitocondrial, produção de estresse oxidativo (entre outros), ele adicionará novos periódicos (e com um fator mais alto de impacto e quartil) que desejem publicar seu trabalho. Se você inclui indicadores moleculares, como fragmentação do DNA, produção e consumo de ATP, translocação de fosfolipídios, etc. Suas opções para publicar em melhores revistas serão aumentadas ainda mais. É evidente que o gametologista não pode aplicar e determinar todas essas técnicas, mas ele pode interpretar seus resultados e dar mais apoio às suas conclusões.

Então, para os jovens pesquisadores que leem este editorial, os convido a procurar e encontrar os colegas mais próximos do seu tópico, se eles estão em outras instituições ou em outros países (¿o que importa?, HOJE MAIS DO QUE NUNCA SABEMOS QUE O MUNDO É UM LENÇO!!!), para falar sob suas pesquisas e como elas podem ser complementadas. Ao publicar, será necessário discutir quem é o primeiro autor ou autor da correspondência ... (em seu primeiro artigo multidisciplinar)!!! e na melhor revista ...

Dr. Iván Valdebenito Isler.

Decano da Faculdade de Recursos Naturais.

Universidade Católica de Temuco. CHILE

Email: ivisler@uct.cl 